\title{
Working
}

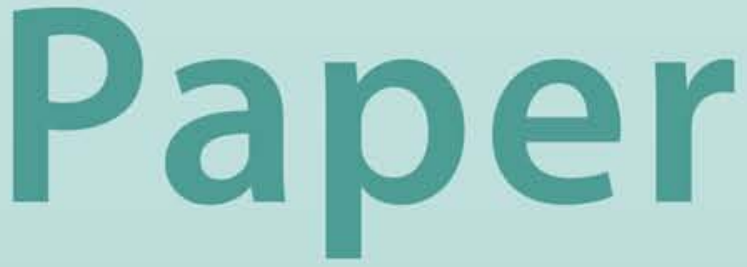


Sticky Inflation and the Real Effects of Exchange Rate-Based Stabilization

Oya Celasun 


\title{
IMF Working Paper
}

\author{
Research Department
}

\section{Sticky Inflation and the Real Effects of Exchange Rate-Based Stabilization}

\author{
Prepared by Oya Celasun ${ }^{1}$
}

Authorized for distribution by Ratna Sahay

July 2003

\begin{tabular}{l} 
Abstract \\
$\begin{array}{l}\text { The views expressed in this Working Paper are those of the author(s) and do not necessarily } \\
\text { represent those of the IMF or IMF policy. Working Papers describe research in progress by the } \\
\text { author(s) and are published to elicit comments and to further debate. }\end{array}$ \\
\hline
\end{tabular}

Exchange rate-based inflation stabilization (ERBS) policies are associated with a boomrecession cycle in economic activity and sustained real exchange rate appreciation. A class of models in the literature has explained these empirical regularities with the lack of credibility of the stabilization plans. The lack-of-credibility models typically assume perfectly forwardlooking pricing behavior without inflation stickiness and attribute the slow decline in inflation to the consumption boom that occurs due to the perceived temporariness of the ERBS policy. This paper tests the empirical validity of forward-looking pricing behavior in Mexico and Turkey, two countries which have experienced ERBS. It finds that the forwardand backward-looking components of inflation weigh approximately equally in pricing behavior, and therefore, that inflation is partially sticky. The paper then develops the theoretical implications of partial inflation stickiness in a lack of credibility model of ERBS and concludes that the presence of stickiness significantly reduces the persistence of the consumption boom predicted by the model, but helps to explain the recession in the late phase of the stabilization.

JEL Classification Numbers:E3, F4

Keywords: Disinflation, Inflation Persistence, Credibility, Mexico, Turkey

Author’s E-Mail Address: Ocelasun@imf.org

\footnotetext{
${ }^{1}$ I would like to thank Guillermo Calvo, Harry Kelejian, Carmen Reinhart, Michel Robe, and John Shea for many useful suggestions. This paper is based on Chapter III of my doctoral dissertation at the University of Maryland, College Park, which was written before I joined the International Monetary Fund.
} 


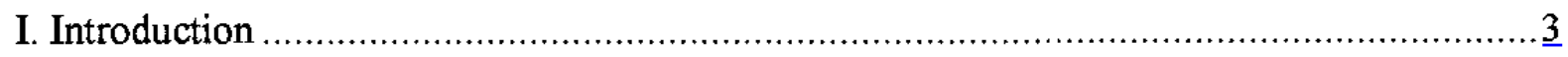

II. Inflation Stabilization and Price-Setting Behavior: The Literature............................... $\mathbb{7}$

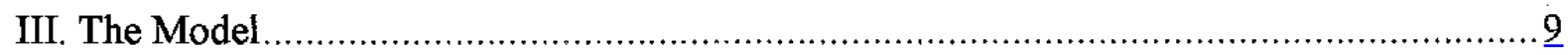

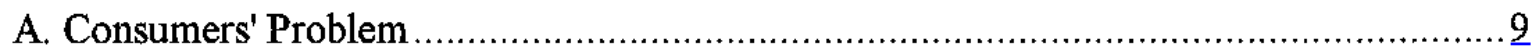

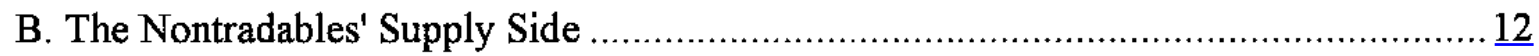

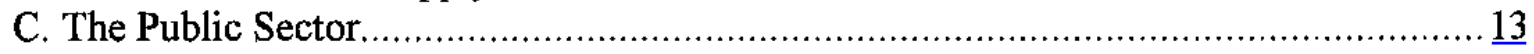

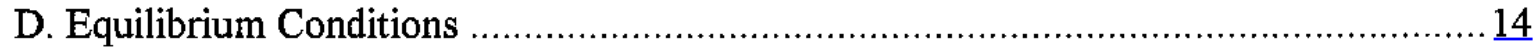

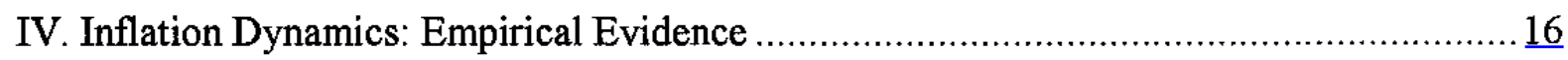

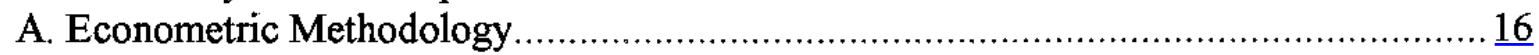

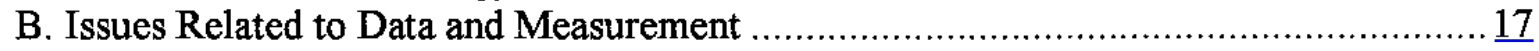

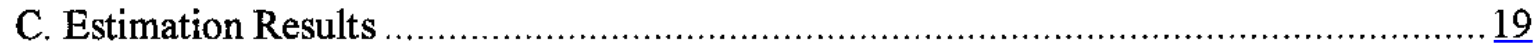

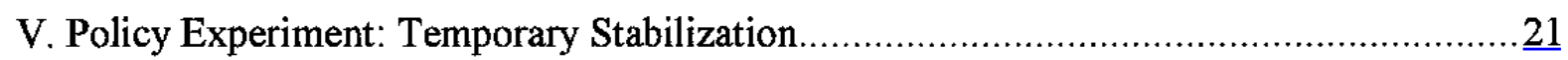

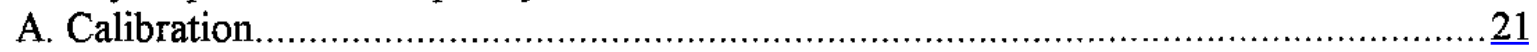

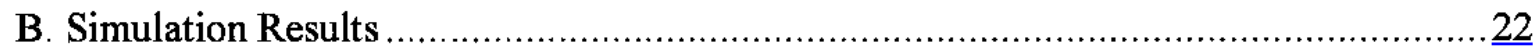

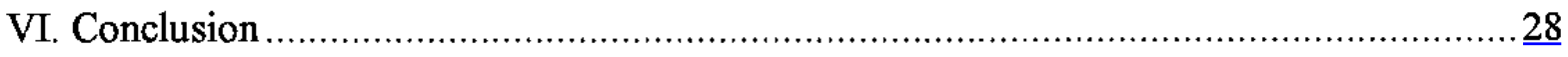

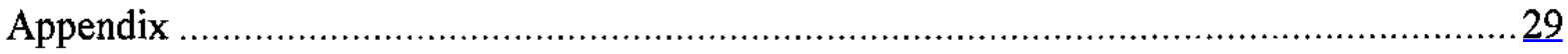

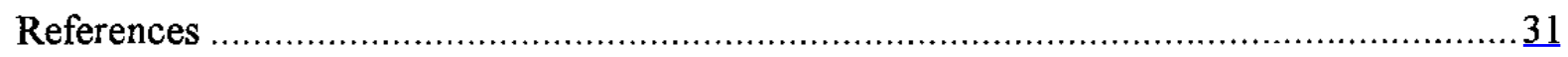

Text Tables

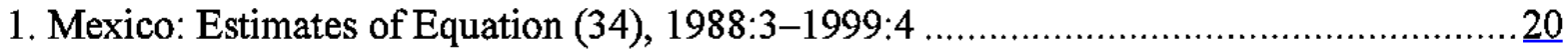

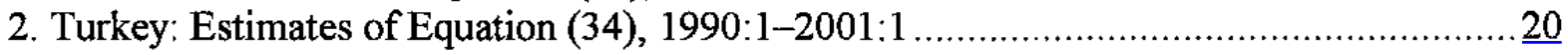

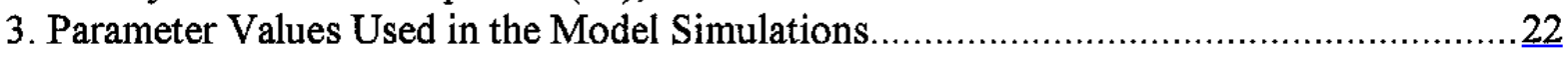

Figures

1a. Mexico: Devaluation and Inflation Rates, 1985:Q1-2000Q1 ….............................

1b. Turkey: Devaluation and Inflation Rates, 1996:Q1-2002Q1 ...................................

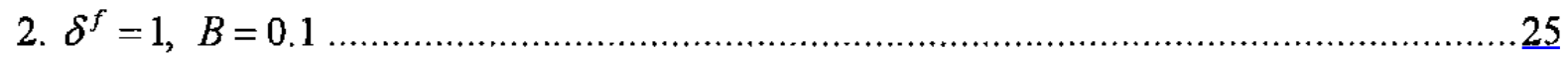

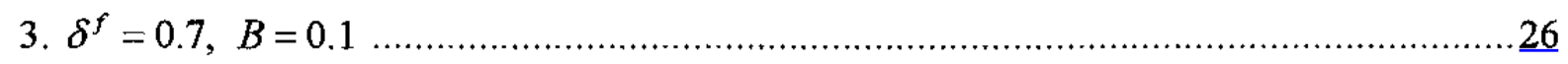

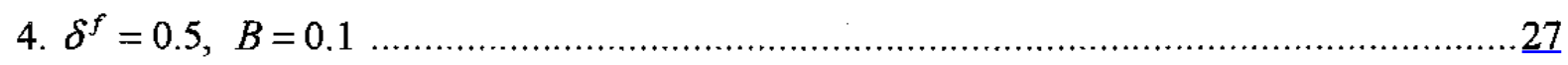




\section{INTRODUCTION}

Since the late 1970s, small open developing economies seeking to reduce inflation have commonly used a preannounced time path of the exchange rate as the nominal anchor for monetary policy, often in the form of a crawling peg. These so-called exchange ratebased stabilization (ERBS) plans have been associated with two empirical regularities. ${ }^{2}$ First, they generate a boom-recession cycle in economic activity. Consumption and output expand in the early stages of the programs, but recessions occur at the later stages of failed and successful stabilizations alike. Second, domestic inflation rates, especially of nontradables, converge to the rate of devaluation slowly, resulting in sustained real exchange rate appreciations.

A key debate in the literature on the real effects of ERBS concerns the extent to which stickiness of inflation slows the rate of convergence of inflation to the rate of exchange rate depreciation. Early contributions to the literature attributed the real exchange rate appreciation to stickiness in domestic inflation caused by backward-looking price setting in the nontradables sector (Dornbusch, 1982, and Rodriguez, 1982). ${ }^{3}$ More recently, Rebelo and Végh (1995) have shown that sticky inflation combined with supply effects of the stabilization can account for the qualitative properties of the business cycle associated with ERBS. At the other end of the spectrum, Calvo (1986) and Calvo and Végh (1993, 1994a) show, in a series of influential papers, that in models with perfectly forward-looking price setting and without inflation stickiness, the persistence of inflation and the boom-recession cycle can be explained by the lack of credibility of the ERBS programs. ${ }^{4}$ This strand of the literature argues that the perceived temporariness of the reduction in the rate of exchange rate depreciation and, thus, nominal interest rates, induce a boom in economic activity as consumers take advantage of lowered costs of holding money for transactions. The excess demand created by the spending boom prevents the domestic inflation rate from declining to the rate of exchange rate depreciation.

${ }^{2}$ See Calvo and Végh (1999) for a comprehensive review of ERBS experiences and literature.

${ }^{3}$ Sticky inflation refers to an inflationary process which displays persistence in the face of serially uncorrelated shocks. It may be caused by backward-looking expectations, indexation in pricing, or nominal rigidities that prevent an updating of inflation expectations. See Fuhrer and Moore (1995); Calvo, Celasun and Kumhof (2001); and Mankiw and Reis (2002) for alternative sticky-inflation models.

${ }^{4}$ A number of other models that do not rely on nominal frictions were advanced to explain the real effects of ERBS policy. However, Rebelo and Végh (1995), who analyze the major competing hypotheses in a unified framework, conclude that the two hypotheses that can qualitatively account for both the real appreciation and the boom-recession cycle simultaneously are the "lack-of-credibility hypothesis" and "sticky inflation combined with supply-side effects." This finding warrants an analysis of the realism of the underpinnings of the two model classes. 
Depending on the mechanism used to explain the empirical regulaties of ERBS, the models can reach starkly different policy conclusions. In models with inflation stickiness generated by backward-looking pricing behavior, the policy recommendation often involves either a gradual decline in the rate of nominal exchange rate depreciation or a timely exit from the peg followed by a corrective devaluation and greater exchange rate flexibility, as argued by Dornbusch and Werner (1994) in the context of Mexico's 1988-94 ERBS plan. If price setting is thought to be completely forward looking and expectations rational and the continued momentum of inflation is explained by the lack of credibility of the exchange rate peg, as in Calvo and Végh (1993), then the preferred policy is to enhance credibility by committing more strongly to the peg-a policy at odds with the alternative advice of "corrective devaluations," as such devaluations will further reduce the credibility of future policies.

The present paper takes a two-pronged approach to assess the validity of these competing hypotheses in explaining the ERBS stylized facts. First, the paper presents estimates of the degree of departure from forward-looking behavior in nontradables inflation in Mexico and Turkey. These empirical estimates are the first for small open economies. ${ }^{5}$ The estimates reveal that forward- and backward-looking terms weigh approximately equally in nontradables inflation dynamics, implying that structural inflation stickiness is a feature of the data that needs to be taken into account for modeling purposes. In light of this evidence, the second part of the paper analyzes how modifying the standard forward-looking model of imperfectly credible ERBS to allow for the estimated degree of inflation stickiness alters its predictions along qualitative and quantitative dimensions. Numerically computed solutions of an optimizing small open economy model show that introducing inflation stickiness significantly reduces the persistence of the consumption boom in a model of imperfectly credible ERBS but helps to explain the recession that occurs in the later stages of policy implementation.

The choice of countries for the empirical analysis reflects the relevance of the issue in Mexico and Turkey, given their recent experience with ERBS plans (in 1988-94 and 200020001 , respectively). The analysis focuses on the consumer prices of nontraded goods and services, where slow inflation convergence is more heavily observed. ${ }^{6}$ Figures $1 \mathrm{a}$ and $1 \mathrm{~b}$ illustrate that during the 1988-94 Mexican program and the 2000-2001 Turkish program, the

\footnotetext{
${ }^{5}$ This empirical question has recently received much attention in the case of industrial countries (see, for instance Galí, Gertler, and López-Salido, 2001, and the references therein).

${ }^{6}$ This may seem at odds with the evidence in Burstein, Neves, and Rebelo (2001) that the appreciation of the United States-Argentina CPI-based real exchange rate following the adoption of the 1991 Convertibility Plan occurred mainly on account of large increases in the distribution margin of tradables prices in the Argentine CPI. However, this conclusion is mostly driven by the fact that the share of nontradables is relatively small in the Argentine CPI basket; their analysis shows that the largest price increases occurred in housing and personal care services, both of which are nontraded services.
} 
Figure 1a. Mexico: Devaluation and Inflation Rates, 1985:Q1-2000Q1

(In percent)

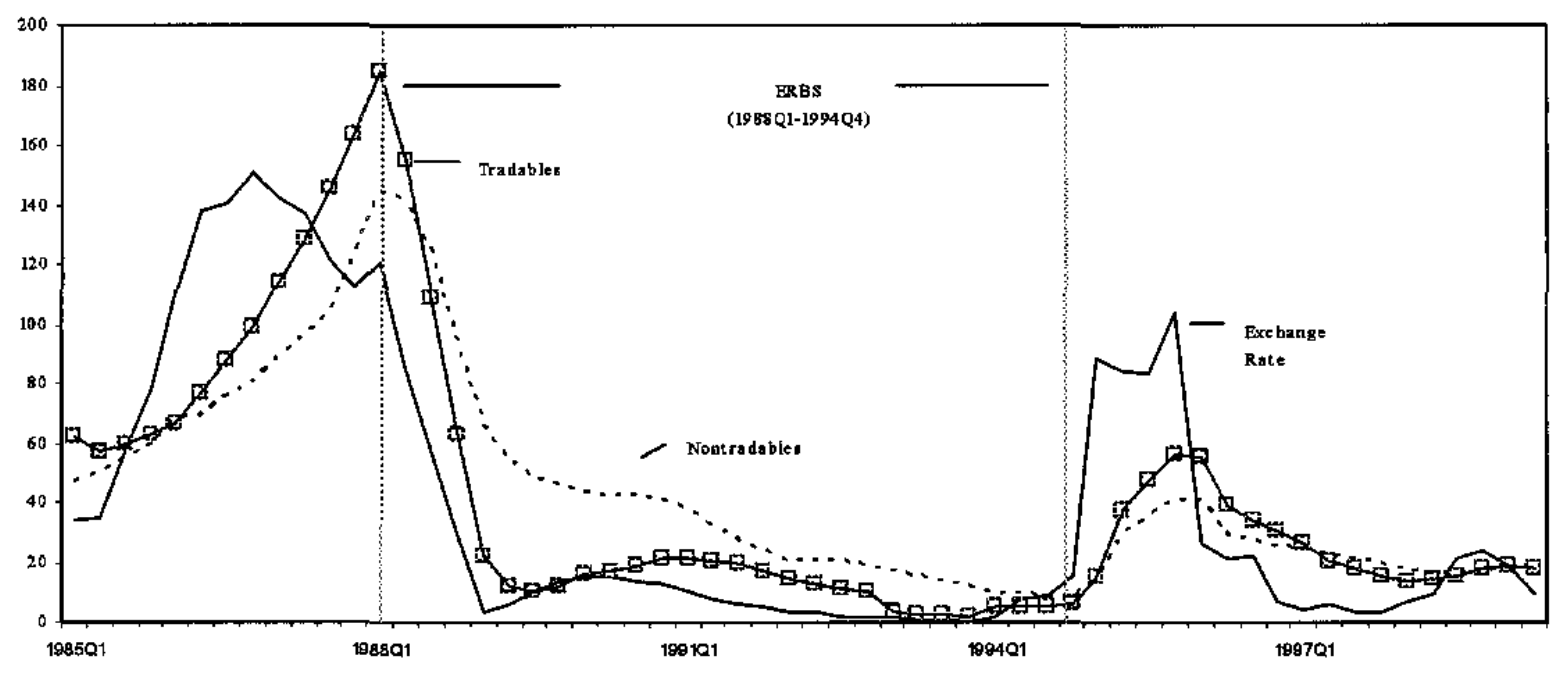

Figure 1b. Turkey: Devaluation and Inflation Rates, 1996Q1-2002Q1

(In percent)

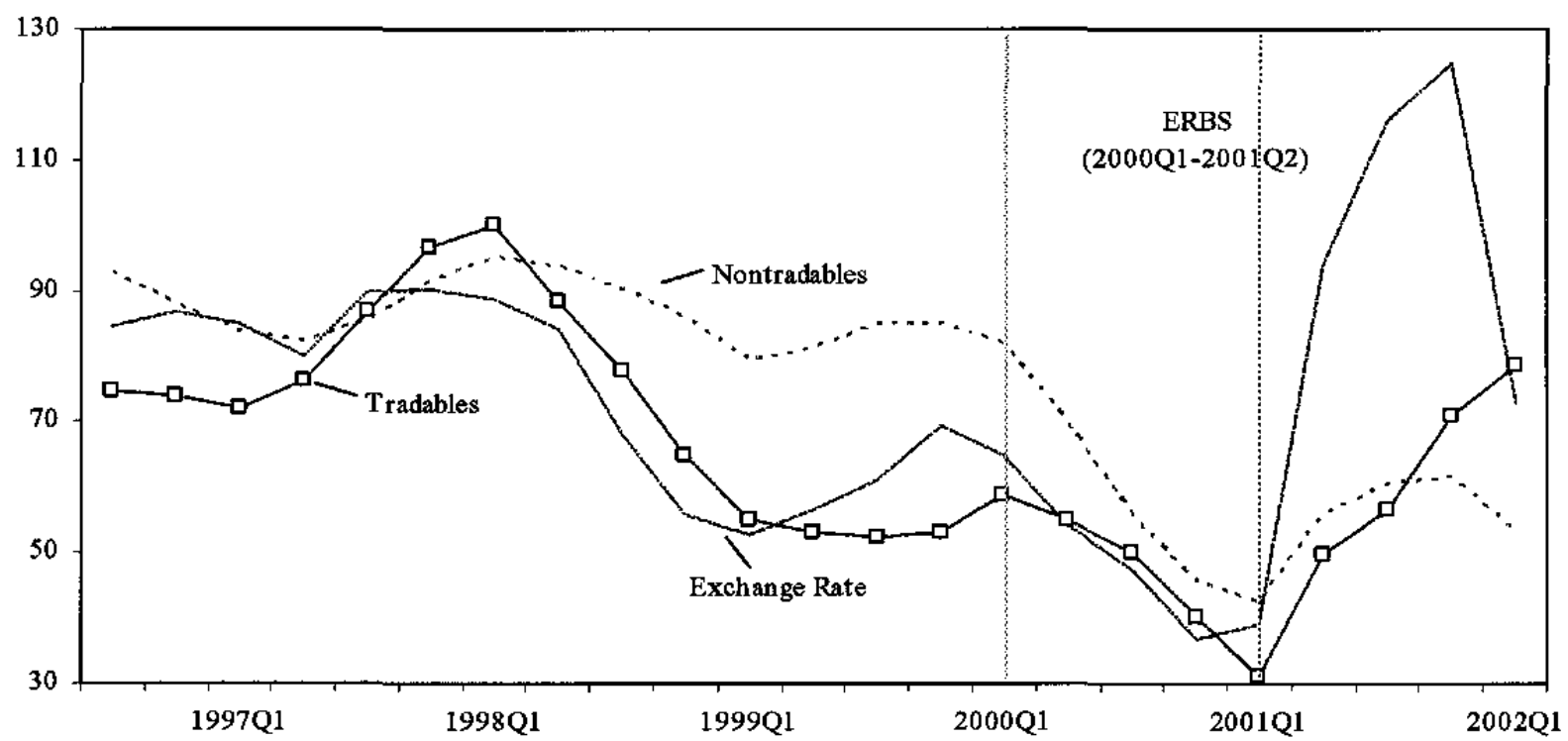


growth of the nontradables component of the consumer price index (CPI) significantly exceeded the growth of the tradables component. ${ }^{7}$ This implies that the increase in the CPI during the ERBS programs was driven mainly by the high inflation in the nontradables sector, since the weights of the two components are almost equal. ${ }^{8}$

The estimated structural inflation equation is derived from a theoretical framework that generalizes the purely forward-looking price-setting model of Calvo (1983) to allow for a fraction of firms to use a backward-looking pricing rule, as in Galí and Gertler (1999) and Ghezzi (2001). The resulting inflation specification relates current inflation to lagged and expected future inflation, as well as to measures of current economic activity that affect pricing decisions, such as excess demand or the gap between marginal costs and prices. The degree of inflation stickiness in the model is measured by the size of the coefficient of lagged inflation, and it is increasing in the fraction of backward-looking price setters and decreasing in the average duration of pricing contracts. The estimated specifications incorporate novel empirical proxies for the determinants of nontradables pricing in small open economies, which are statistically significant in most regressions.

The empirical evidence on the degree of inflation stickiness is used in the second part of the paper, which compares the predictions of a small open economy model of imperfectly credible ERBS under varying degrees of inflation stickiness. Imperfect credibility is modeled as a reduction in the rate of exchange rate depreciation which is expected to be only temporary by the public, with an exogenously given period of expected reversal. The perceived temporariness of the decline in the rate of depreciation and nominal interest rate induces intertemporal consumption substitution away from the future and toward the ERBS period, which sets in motion a boom-recession cycle in economic activity. Numerical computations of the solution paths of the model with an empirically relevant degree of inflation stickiness differ in two important ways from the predictions of the same model without stickiness. First, since inflation stickiness resulting from backward-looking pricing implies that high levels of past inflation contribute to high inflation after the inception of the program, it results in a faster real exchange rate appreciation in the initial stages of the ERBS. By contrast, in the baseline model with forward-looking pricing and without inflation stickiness, the excess demand created by the consumption boom is the only factor that prevents inflation from declining to the rate of exchange rate depreciation. The faster increase in the price of nontradables relative to tradables in the sticky inflation case implies a much faster reduction in nontradables consumption, implying, in turn, a much less persistent consumption boom in the initial stages of the stabilization. Thus, the model with inflation stickiness cannot overcome the weakness of the fully forward-looking imperfect credibility model in explaining the observed consumption booms; the presence of structural inflation

${ }^{7}$ Celasun (2001) analyzes the inflation dynamics of tradable goods prices in Mexico and Turkey, and finds that price setting is almost completely forward looking, with the main determinant of tradables price setting estimated to be foreign prices.

${ }^{8}$ The weight of nontradables in the CPI basket is approximately equal to 40 percent in both countries during 1988-2000. 
stickiness worsens its already imperfect performance in matching the magnitudes of actual consumption booms (Reinhart and Végh, 1995; Rebelo and Végh, 1995) and casts some doubt on the lack-of-credibility hypothesis as the sole mechanism behind the ERBS syndrome.

The second notable impact of inflation stickiness on the predictions of the imperfectly credible ERBS model is that stickiness in inflation eventually brings about an overappreciation of the real exchange rate, in the sense that the real exchange rate overshoots its steady-state value, prior to the expected time of the abandonment of the program. The overappreciation of the real exchange rate brings about excess supply and a contraction in the nontradable goods sector, as suggested in the early work of Dornbusch (1982) and Rodriguez (1982). This implies that in a model with inflation stickiness, any mechanism that generates an initial consumption boom can explain the qualitative properties of the ERBS business cycle, namely the appreciation of the real exchange rate and the boom-recession cycle in economic activity.

The rest of the paper is organized as follows. Section II provides a brief survey of the literature on the real effects of ERBS programs and price-setting behavior. Section III presents the small open economy model, the nontradables supply side of which incorporates backward- and forward-looking pricing behavior. Section IV presents estimates of the structural equation of the model which governs short-term nontradables inflation dynamics. Section V presents the numerical computations of solution paths of the model under a temporary ERBS and compares the dynamics under various degrees of inflation stickiness. Section VI concludes.

\section{Inflation Stabilization AND PRICE-SetTing BehaVIoR: The LiteratuRe}

Early studies by Rodriguez (1982) and Dornbusch (1982) suggest that inflation stickiness causes both the boom and the recession in ERBS episodes. With sticky inflation and perfect capital mobility, a reduction in the rate of devaluation leads to a reduction in nominal and real interest rates. Assuming that aggregate demand depends negatively on the real interest rate and positively on the real exchange rate, both authors argue that the drop in real interest rates initially causes an expansion of aggregate demand, but the sustained real exchange rate appreciation due to inflation stickiness eventually leads the economy into a recession. Calvo and Végh (1994), however, show that an initial consumption boom is hard to reconcile with a permanent reduction in the rate of devaluation in a utility maximizing framework with sticky inflation in the absence of any wealth effects of the ERBS.

\footnotetext{
${ }^{9}$ Specifically Calvo and Vegh (1994) show that an initial consumption boom occurs in an optimizing model only if the elasticity of intertemporal substitution exceeds the elasticity of intratemporal substitution. The fact that this condition was not supported by available empirical evidence (Ostry and Reinhart, 1992), cast doubt on the inflation stickiness channel as an explanation of the initial ERBS consumption boom. More recent evidence, however, suggests the condition may hold in economies where the nontradable sector is small (Cashin and McDermott, 2003).
} 
Calvo and Végh (1993) suggest that the persistence of domestic inflation can instead be explained by the lack of credibility of the ERBS program. In their framework, the public expects the rate of devaluation and the nominal interest rate to increase back to their prestabilization levels in finite time due to lack of policy credibility. Since money holdings facilitate transactions and the effective price of consumption is increasing in the nominal interest rate, temporarily low nominal interest rates induce intertemporal substitution of tradables consumption towards the present. The increased demand prevents the inflation rate of nontradables from converging to the rate of depreciation even though inflation is not inherently sticky, bringing about a sustained real appreciation along with the consumption boom. At the time of the expected policy reversal, tradables and nontradables consumption drop on account of the lower level of foreign assets and higher nominal interest rates. In this framework, a permanent decline in the rate of devaluation induces no effects on output and consumption as there is an immediate convergence of the rate of inflation to the rate of devaluation. Therefore, the perceived temporariness of the stabilization effort is key in generating the boom-bust cycle and the real appreciation.

Other studies have stressed the wealth effect of the fiscal adjustment that often accompanies the exchange rate peg as a factor that gives rise to a higher level of consumption. Helpman and Razin (1987) emphasized the reduction in the inflation tax, Drazen and Helpman (1988) the expectation of a future reduction in government spending and Rebelo (1993) the overall fiscal correction in generating positive wealth effects. Rebelo and Végh (1995) have shown that the fiscal adjustment channel does not account for the late recession, and its qualitative and quantitative performance in matching the ERBS stylized facts very much depends on the size and composition of fiscal adjustment.

Another strand of the literature stresses the effects of the stabilization on the supplyside of the economy. Roldos (1995) and Uribe (1997) show that a permanent stabilization increases investment, since the transaction costs associated with capital investment falls. As resources that were previously absorbed by high transaction costs are freed up, wealth increases, and so does consumption. In other scenarios, such as in Lahiri (1996), nominal interest rates induce a distortion between consumption and leisure, therefore the reduction in inflation and nominal interest rates increase the supply of labor, the desired capital stock and investment. While these scenarios explain the initial boom in consumption via wealth effects, they leave the late recession unexplained. Rebelo and Végh (1995) show that this can be remedied by assuming either sticky wage inflation, or sticky inflation in the nontradables sector, since the over-appreciation of the real exchange rate due to sticky inflation generates an eventual recession. Thus the scenario with supply-side effects and inflation stickiness can explain the qualitative features of the business cycle associated with ERBS. ${ }^{10}$

\footnotetext{
${ }^{10}$ More generally, increased wealth combined with sticky inflation can explain the boomrecession cycle. Bruno (1993, Chapter 5) argues that in the 1985 Israeli disinflation, positive wealth effects stemming from perceived increases in financial wealth gave rise to an initial consumption boom. This delayed the "usual" contraction associated with real factor price overshooting (due to sticky wage inflation) during disinflation.
} 
Finally, De Gregorio, Guidotti and Végh (1998) emphasize the role of durable goods. If the purchases of durables are governed with $(\mathrm{S}, \mathrm{s})$ rules, a positive wealth effect under ERBS causes an initial bunching of durables purchases and a slump thereafter. Their scenario does not address either the boom-recession cycle in the nontradables sector or the real exchange rate appreciation, but it can be shown that if there are nominal rigidities in the nontradables sector, the initial increase in durables (tradables) consumption will cause a boom also of nontradables consumption since the real exchange rate can not adjust on impact. Moreover, if inflation is sticky, the over-appreciation of the real exchange rate will cause a contraction in the nontradables sector following the initial boom.

Rebelo and Vegh (1995) compare the competing hypotheses in a unified framework, and single out the lack-of-credibility hypothesis and sticky inflation combined with supply side effects as the two hypotheses that can account for both the boom recession cycle and real appreciation. An understanding of the nature of price setting and the degree of inflation stickiness would help in gauging which of these scenarios are more realistic characterizations of the ERBS syndrome.

\section{THE MODEL}

This section outlines a simple model to study the effects of an exchange rate based stabilization policy. First, the consumers optimization problem, the supply side, and the public sector are described. The model is then closed with the equilibrium conditions and an equation system that governs the dynamics of the model economy is derived.

\section{A. Consumers' Problem}

The small open economy under consideration operates under perfect foresight and consists of infinitely lived identical consumers who maximize lifetime utility derived from their consumption of tradable and nontradable goods $c_{t}^{*}$ and $c_{t}$ :

$$
\underset{\left\{c_{t}, c_{t}^{\prime}, m_{t}\right\}_{t=0}^{\infty}}{\operatorname{Max}} \sum_{t=0}^{\infty}\left(\frac{1}{1+r}\right)^{t}\left[(1-q) \log c_{t}^{*}+q \log c_{t}\right] .
$$


To ensure the existence of a steady state, it is assumed that the consumers' discount rate of future utility equals the international rate of interest, $r$.

Two financial assets are available to the consumers, an international bond, $b_{t}$, with constant return $r$ in foreign currency, and domestic money, $M_{t}$. In each period, consumers receive a constant endowment of tradables, $y^{*}$, the output of nontradables $y_{t}$, and a lumpsum (tradables) transfer from the government $\tau_{t}$.

The law of one price holds for tradables. Their price in domestic currency equals $E_{\mathrm{t}} P_{\mathrm{t}}^{*}$ where $E_{t}$ is the nominal exchange rate and $P_{t}^{*}$ is the foreign currency price of nontradables which is normalized to one for convenience. $P_{t}$ denotes the price level of nontradables. The real exchange rate is denoted by $e_{t} \equiv E_{t} / P_{t}$. Perfect capital mobility holds, therefore the domestic nominal interest rate $i_{t}$ satisfies the uncovered interest parity condition:

$$
1+i_{t}=(1+r)\left(1+\varepsilon_{t+1}\right)
$$

where $\varepsilon_{t+1} \equiv \frac{E_{t+1}-E_{t}}{E_{t}}$ is the nominal rate of devaluation between time periods $t$ and $t+1$.

Transactions are assumed to be costly and following Kimbrough (1986), real monetary holdings, $m_{t}=M_{t} / E_{t}$, are assumed to reduce transaction costs. ${ }^{11}$ The effective price of purchases equals $\left(1+s\left(v_{t}\right)\right)$, where $s\left(v_{t}\right)$ denotes transaction costs. $s\left(v_{t}\right)$ is strictly increasing in the expenditure velocity of money, $v_{t}$, where

$$
v_{t}=\frac{c_{t}^{*}+\frac{c_{t}}{e_{t}}}{m_{t}}
$$

and is assumed to be a convex function of expenditure and real balances. To satisfy this assumption, the following functional form is assumed for $s\left(v_{t}\right)$ in the numerical solutions:

$$
s\left(v_{t}\right)=k_{o} v_{t}^{k_{1}}, \quad k_{o}, k_{1}>0
$$

\footnotetext{
11 Transaction costs that are decreasing in real monetary holdings and cash-in-advance constraints are widely used in the literature to motivate holdings of money and to model the basic monetary distortion posed by inflation. See for example Reinhart and Végh (1995) or Rebelo and Végh (1995).
} 
The period $t$ flow budget constraint of the consumer in terms of tradables is

$$
b_{t-1}(1+r)+\frac{m_{t-1}}{1+\varepsilon_{t}}+y^{*}+\frac{y_{t}}{e_{t}}+\tau_{t}=b_{t}+m_{t}+\left(1+s\left(v_{t}\right)\right)\left(c_{t}^{*}+\frac{c_{t}}{e_{t}}\right) .
$$

When combined with the no Ponzi game condition, $\lim _{t \rightarrow \infty} \frac{b_{t}+m_{t}}{(1+r)^{t}} \geq 0$, the flow budget constraint can be converted into the lifetime budget constraint:

$$
b_{-1}(1+r)+\frac{m_{-1}}{1+\varepsilon_{1}}=\sum_{i=0}^{\infty}\left(\frac{1}{1+r}\right)^{t}\left[\frac{i_{t} m_{t}}{1+i_{t}}+\left(1+s\left(v_{t}\right)\right)\left(c_{t}^{*}+\frac{c_{t}}{e_{t}}\right)-y^{*}-\frac{y_{t}}{e_{t}}+\tau_{t}\right] .
$$

This equation states that the present value of future spending net of income equals the present value of assets.

The representative individual maximizes his or her utility given in equation (1) by choosing the sequence $\left\{c_{t}, c_{t}^{*}, m_{t}\right\}_{t=0}^{\infty}$ subject to the lifetime budget constraint (6), taking as given the initial financial assets, $b_{-1}$ and $m_{-1}$, and the sequences $\left\{\varepsilon_{t}, \tau_{t}^{*}, e_{t}\right\}_{t=0}^{\infty}$. The optimization problem yields the following first order conditions:

$$
\begin{gathered}
c_{t}^{*}=\frac{q}{\lambda}\left(1+s\left(v_{t}\right)+v_{t} s^{\prime}\left(v_{t}\right)\right)^{-1}, \\
\frac{q}{1-q} \frac{c_{t}}{c_{t}^{*}}=e_{t}, \\
\frac{i_{t}}{1+i_{t}}=v_{t}^{2} s^{\prime}\left(v_{t}\right),
\end{gathered}
$$

where $\lambda$, is the lagrange multiplier associated with the present value budget constraint (6) or equivalently, the marginal utility of wealth. Equation (7) states that at the optimum, the marginal utility of consuming tradable goods is equal to the product of the marginal utility of wealth, $\lambda$, and the effective price of tradables consumption, $\left(1+s\left(v_{t}\right)+v_{t} s^{\prime}\left(v_{t}\right)\right)$.

Equation (8) equates the marginal rate of substitution between tradables and nontradables consumption to their relative price. With logarithmic utility, this implies that the shares of nominal expenditures spent on the two goods are constant. Equation (9) entails an implicit relationship between the nominal rate of interest and the expenditure velocity of money:

$$
v_{t}=v\left(i_{t}\right), \quad v^{\prime}>0 .
$$


Therefore the effective price of consumption in time $t$ is an increasing function of the domestic nominal interest rate between time $t$ and $t+1$.

\section{B. The Nontradables' Supply Side}

In the nontradables sector, prices are set in advance and output is demand determined. Following Calvo (1983), firms are assumed to face exogenous constraints on the timing of price changes. In this setting, a large number of firms post new prices when they receive a random signal. The probability of receiving a signal in any period is $1-\gamma$ for each firm. This implies, assuming that the number of firms is large, a fraction $1-\gamma$ of firms change their price in any given period, while the rest keep their price unchanged. A firm that receives a signal in period $t-1$ will choose a price which will apply from period $t$ onwards and remain effective until the occurrence of the next signal. Firms fall into two categories as to how they set prices. A constant share $\omega$ of firms set prices in a forward looking manner while the rest are backward looking. The average newly set price (in logarithms), $V_{t}$, is a linear combination of prices posted by backward and forward looking price setters, $V_{t}^{b}$ and $V_{t}^{f}$ respectively:

$$
V_{t}=\omega V_{t}^{b}+(1-\omega) V_{t}^{f}
$$

Backward-looking price setters who receive a price-change signal in period $t-1$ update the newly-set price in period $t-1$ by the most recently observed inflation rate: ${ }^{12}$

$$
V_{t}^{b}=V_{t-1}+\pi_{t-1}
$$

where $\pi_{t}=P_{t}-P_{t-1}$ and $P_{t}$ is the logarithm of the price level-as defined below. Following Calvo (1983), the new price chosen by forward-looking firms, $V_{t}^{f}$, is a weighted average of expected optimal future prices that the firms would choose if they could reset their prices in each period. The period $s$ optimal price equals the average price level in that period, $P_{s}$, plus

an excess demand term, $e d_{s}$, where $e d_{s} \equiv \log c_{s}-\log \bar{y}$, and $\bar{y}$ is the constant level of full employment nontradables output. ${ }^{13}$ The weight on period $s$ optimal price, where $s>t$, is the probability that the firm gets its next signal in period $s$ :

$$
V_{t}^{f}=(1-\gamma) \sum_{k=0}^{\infty} \gamma^{k}\left(P_{t+k}+\beta e d_{t+k}\right)
$$

\footnotetext{
12 The specification of the backward-looking pricing rule follows Obstfeld (1995), Galí and Gertler (1999) and Ghezzi (2001).

${ }^{13}$ This pricing rule is derived in the Appendix from a profit maximization model of monopolistically competitive price setting.
} 
The average price level (in logarithms) is the average of previously posted prices weighted by the probability that these prices are still in force:

$$
P_{t}=(1-\gamma) \sum_{k=1}^{\infty} \gamma^{k-1} V_{t-k}
$$

It follows from equations (13) and (14) that the evolution of $V_{t}^{f}$ and $P_{t}$ can be described by the difference equations

$$
V_{t}^{f}=(1-\gamma)\left(P_{t}+\beta e d_{t}\right)+\gamma V_{t+1}^{f}
$$

and

$$
P_{t}=(1-\gamma) V_{t-1}+\gamma P_{t-1}
$$

Equations (11), (12), (15), and (16) can be combined to yield the equation that governs nontradables inflation dynamics:

$$
\pi_{t}=\left(1-\delta^{f}\right) \pi_{t-1}+\delta^{f} \pi_{t+1}+B\left(\log c_{t}-\log \bar{y}\right)
$$

where

$$
\begin{aligned}
& \delta^{f}=\frac{\gamma}{\omega+\gamma}, \\
& B=\frac{\beta(1-\omega)(1-\gamma)^{2}}{\omega+\gamma} .
\end{aligned}
$$

\section{The Public Sector}

The public sector is assumed to rebate transaction costs to the households in a lumpsum manner, implying that there are no wealth effects associated with monetary policy. ${ }^{14}$ The flow budget constraint of the public sector takes the form:

$$
d_{t}=d_{t-1}(1+r)+m_{t}-\frac{m_{t-1}}{1+\varepsilon_{t}}-\tau_{t}-\left(c_{t}^{*}+\frac{c_{t}}{e_{t}}\right) s\left(v_{t}\right)
$$

\footnotetext{
${ }^{14}$ This assumption enables us to isolate and focus on the intertemporal substitution effects associated with temporary stabilization policy.
} 
where $d_{t}$ is the stock of foreign bonds held by the government. Combined with the no Ponzigame condition, $\lim _{t \rightarrow \infty} \frac{d_{t}-m_{t}}{(1+r)^{t}} \geq 0$, the flow budget constraint can be converted into the lifetime budget constraint of the public sector:

$$
d_{-1}(1+r)-\frac{m_{-1}}{1+\varepsilon_{0}}=\sum_{t=0}^{\infty}\left(\frac{1}{1+r}\right)^{t}\left[\tau_{t}+\left(c_{t}^{*}+\frac{c_{t}}{e_{t}}\right) s\left(v_{t}\right)+\frac{i_{t} m_{t}}{1+i_{t}}\right]
$$

This equation implies that the present value of future government spending on transfers and transaction cost rebates to the households, net of seigniorage revenue, must equal the value of initial public sector assets.

\section{Equilibrium Conditions}

Output in the nontradables sector is demand determined:

$$
c_{t}=y_{t} \quad \forall t
$$

Combining the nontradables market clearing condition (20) with the consumers' and public sectors' intertemporal budget constraints, (6) and (19), yields the overall budget constraint of the economy:

$$
f_{-1}(1+r)+\frac{(1+r)}{r} y^{*}=\sum_{t=0}^{\infty}\left(\frac{1}{1+r}\right)^{t} c_{t}^{*}
$$

which states that the initial aggregate holdings of foreign assets, $f_{-1} \equiv d_{-1}+b_{-1}$, plus the present worth of tradables income should equal the present value of tradables expenditure. The current account of the economy evolves according to:

$$
f_{t}-f_{t-1}=r f_{t-1}+y^{*}-c_{t}^{*}
$$

Equations (7) and (21) can be combined to determine $\lambda$, the value of the lagrange multiplier in the consumers' optimization problem:

$$
\lambda=\frac{1}{f_{-1}(1+r)+\frac{(1+r)}{r} y^{*}} \sum_{t=0}^{\infty}\left(\frac{1}{1+r}\right)^{t} \frac{q}{q+s\left(v_{t}\right)+v_{t} s^{\prime}\left(v_{t}\right)} .
$$

Substituting the expression in equation (22) into equation (7) yields the path of optimal tradables consumption, $\left\{c_{t}^{*}\right\}_{t=0}^{\infty}$ as a function of the path of the policy variable, 
$\left\{\varepsilon_{t}^{*}\right\}_{t=0}^{\infty}$ (through the dependence of the nominal interest rate $i$, and hence $v$, on $\varepsilon$ ), and the exogenous variables in the model; the international real interest rate, $r$, the initial value of foreign asset holdings, $f_{-1}$, and the constant endowment of tradable goods, $y^{*}$. Given $\left\{c_{t}^{*}\right\}_{t=0}^{\infty}$, the perfect foresight paths of nontradables' consumption, $c$, and inflation, $\pi$, are determined by a system consisting of equation (17) and the first differenced form of equation (8):

$$
\begin{aligned}
& \pi_{t}=\left(1-\delta^{f}\right) \pi_{t-1}+\delta^{f} \pi_{t+1}+B\left(\log c_{t}-\log \bar{y}\right) \\
& \log c_{t}=\log c_{t-1}+\log \left(1+\varepsilon_{t}\right)-\pi_{t}+\log c_{t}^{*}-\log c_{t-1}^{*}
\end{aligned}
$$

Assuming that the economy in period $t=-1$ is at the steady state associated with a constant rate of nominal devaluation, $\varepsilon^{H}$, and the rate of devaluation is expected to remain at $\varepsilon^{H}$ indefinitely, the perfect foresight path of the economy for the period $0 \leq t<\infty$ is determined as follows. By the uncovered interest parity (2) the nominal interest rate is constant:

$$
i=(1+r)\left(1+\varepsilon^{H}\right)-1 .
$$

By equations (7) and (22) this implies that consumption of tradables is also constant:

$$
c^{*}=y^{*}+r f_{-1}
$$

By the system of equations (23) the steady state values of $c$ and $\pi$ are:

$$
\begin{gathered}
c=\bar{y}, \\
\pi=\varepsilon^{H} .
\end{gathered}
$$

The steady state value of the real exchange rate is:

$$
e=\frac{q}{1-q} \frac{\bar{y}}{\left(y^{*}+r f_{-1}\right)}
$$

In this model, the response of nontradables inflation, $\pi$, and demand, $c$, to a reduction of the rate of exchange rate depreciation depend crucially on the magnitude of $\delta^{f}$, the weight on expected future inflation in the structural inflation equation(17). The next section presents empirical estimates of this parameter based on quarterly data from Mexico and Turkey, and the estimates are used for numerical computations of model solutions under a temporary ERBS experiment in Section V. 


\section{INFLATION DYNAMICS: EMPIRICAL EVIDENCE}

This section presents econometric estimates of the importance of backward and forward looking terms in the structural inflation equation using data from Mexico (1988:Q31999:Q4) and Turkey (1990:Q1-2001:Q1). ${ }^{15}$ In the econometric estimations of equation (17), the future rate of inflation, $\pi_{t+1}$, is replaced by its expected value:

$$
\pi_{t}=\left(1-\delta^{f}\right) \pi_{t-1}+\delta^{f} E_{t} \pi_{t+1}+X_{t} B+u_{t} .
$$

$X_{t}$ is a vector of forcing variables that proxy excess demand for nontradables, $E_{t}$ is the expectations operator with the information set containing variables dated $t-1$ and earlier, and $u_{t}$ is an unobservable supply shock. ${ }^{16}$

\section{A. Econometric Methodology}

Forward-looking price setters are assumed to form expectations rationally. This implies that the expectation of a variable equals the sum of its actual value and a forecast error that is orthogonal to the set of information available when the expectation is formed. Equation (29) can then be rewritten as:

$$
\pi_{t}=\left(1-\delta^{f}\right) \pi_{t-1}+\delta^{f} E_{t} \pi_{t+1}+X_{t} B+\xi_{t}+u_{t}
$$

where $\xi_{t}=E_{t} \pi_{t+1}-\pi_{t+1}$ is an unobservable forecast error. $\xi_{t}$, is not orthogonal to $\pi_{t+1}$, which necessitates the use of instrumental variables in estimation. Moreover, the composite disturbance term, $\xi_{t}+u_{t}$, is not necessarily homoskedastic, and as observed by Hayashi (1980), it has an MA(1) structure. ${ }^{17}$ To account for the endogeneity problem, as well as the MA(1) structure and potential heteroskedasticity of the errors, the generalized method of moments (GMM) estimator of Hansen (1982) is used to estimate equation (30). The orthogonality condition that forms the basis of the GMM estimation is:

$$
E_{t}\left\{\pi_{t}-\left(1-\delta^{f}\right) \pi_{t-1}-\delta^{f} \pi_{t+1}-X, B \mid I_{t}\right\}=0
$$

where $I_{t}$ is the set of information available when the price that applies from period $t$ onwards is set:

${ }^{15}$ The data series were obtained from the Central Bank of Mexico, the Central Bank of Turkey, and the State Planning Organization of Turkey.

${ }^{16}$ Estimates of the structural parameters $\omega, \gamma$, and $\beta$ are not needed for the numerical simulations of the model.

${ }^{17}$ Note that this does not imply that the lagged value of the endogenous variable is not a valid instrument, since it is contained in the information set. 


$$
I_{t}=\left\{\pi_{t-i}, X_{t-i}, Z_{t-i}\right\}_{i=1}^{n}
$$

$Z_{t}$ is the vector of instrumental variables that may be relevant for the pricing decision in addition to $X_{t}$. Contemporaneous values of $X_{t}$, and $Z_{t}$ are not included in the information set, since they are not observed with certainty when the price $V_{t}^{f}$ is chosen.

The excess of the number of instruments over the number of estimated parameters allows a test of the overidentifying restrictions (Hansen, 1982), which is a joint test of the specification and the validity of the instruments. The test statistic $(J)$ is the minimized objective function of the GMM estimation, and under the null hypothesis that the model is not misspecified, it has a chi-squared distribution with $m$ degrees of freedom, where $m$, the number of over-identifying restrictions, is equal to the number of instruments minus the number of parameters.

The inflation equation is nonlinear in the structural parameters but linear in the variables. Hence, for any structural inflation equation there corresponds a linear representation where the "reduced form" coefficients on the explanatory variables are conglomerate functions of the structural parameters. ${ }^{18}$ Whether the estimates of these reduced form coefficients are statistically significant is an important indicator of the performance of the model in matching the data.

\section{B. Issues Related to Data and Measurement}

An issue in the estimation of equation (30) is that the quarterly demand for nontradables is not observed. To obtain a proxy of nontradables demand based on observable variables, we use a linear approximation to the first order condition of the consumers' problem which equates the marginal rate of substitution between nontradables and tradables consumption levels to the real exchange rate. For a generic utility function $u\left(c_{t}^{*}, c_{t}\right)$ of tradable and nontradable goods' consumption, the first-order linear approximation to the first order condition $\frac{u_{c}\left(c_{t}^{*}, c_{t}\right)}{u_{c}\left(c_{t}^{*}, c_{t}\right)}=e_{t}$, yields the relationship:

$$
c_{t} \approx \alpha_{0}+\alpha_{1} e_{t}+\alpha_{2} c_{t}^{*}
$$

${ }^{18}$ For example, the reduced-form coefficient on expected future inflation, $\delta^{f}$, equals $\frac{\gamma}{\omega+\gamma}$. 
implying that, the demand for nontradables is proportional to the demand for tradables and the relative price of tradables with respect to nontradables, i.e. the real exchange rate. ${ }^{19}$ It is further assumed that excess demand for nontradables is proportional to excess demand for tradables and the deviation of the real exchange rate from its equilibrium value. Denoting the deviation of the real exchange from its equilibrium value by $\tilde{e}_{t}$, and the excess demand for nontradables by $\tilde{c}_{t}^{*}$, the estimated inflation equation is derived by substituting this approximation as $X_{t}$ in equation (30):

$$
\pi_{t}=\alpha_{0}+\left(\mathbf{l}-\delta^{f}\right) \pi_{t-1}+\delta^{f} \pi_{t+1}+\alpha_{1} \tilde{e}_{t}+\alpha_{2} \tilde{c}_{t}^{*}+\xi_{t}+u_{t},
$$

Given that there are no model restrictions that allow us to identify any of the structural parameters $\omega, \gamma$ and $\beta$, the reduced form parameters of equation (34), i.e. $\delta^{f}, \alpha_{0}, \alpha_{1}$, and $\alpha_{2}$, are estimated.

In the regressions, the deviation of the real exchange rate from its equilibrium value is proxied by its deviation from a fitted linear trend. To check robustness, two different measures are used for tradables excess demand: the imports-to-GDP ratio and the current account-to-GDP ratio. Inflation series are the quarterly first log-differences of nontradables price indices. Nontradables price indices are constructed from the subcomponents of the consumer price index (CPI). Indices of Mexican consumer durables and services prices were used as tradables and nontradables prices, respectively ${ }^{20}$ For Turkey, similar indices were constructed using the subcategories of the CPI. The tradables price index is constructed as a weighted sum of the housing appliances and furniture, clothing and footwear, and transportation and communications price indices, and the nontradables index of the housing, health services and personal care, culture, training and entertainment price indices. The weights of the subindices were estimated from an OLS regression of the CPI to the subindices for the period 1987:1-2000:1. ${ }^{21}$ The real exchange rate is computed as the ratio of the tradables to nontradables price index for Mexico, as the ratio of the exchange rate to the nontradables price index for Turkey, given the difficulties with the measurement of nontradables versus tradables prices.

${ }^{19}$ For any concave utility function $\left(u_{o c}, u_{c^{\circ} c^{\circ}}<0\right)$ that satisfies $u_{c c^{*}}, u_{\dot{c}_{c}}>0$ (tradables and nontradables consumption are complements), $a_{1}$ and $a_{2}$ are positive. If $u_{c c^{*}}, u_{c_{c}}<0$, that is if tradables and nontradables consumption are substitutes, the signs of $a_{1}$ and $a_{2}$ are indeterminate

${ }^{20}$ This dataset was obtained from the Central Bank of Mexico, with the kind help of Juan Trevino.

${ }^{21}$ The weights were estimated to be 0.30 for food, 0.10 for clothing and footwear, 0.14 for housing appliances and furniture, 0.01 for health and personal care services, 0.06 for transportation and communications, 0.05 for culture, training and entertainment, and 0.35 for housing. 
The constant term in the equation is allowed to vary across three sub-periods in Mexico, namely 1988:Q2-1991:Q3, 1991:Q4-1994:Q4, and 1995:Q1-1999:Q4, to account for the large variation in average inflation and thus potentially different markup rates across different episodes. In the case of Turkey, inflation was relatively stable throughout the sample period, so the constant term is assumed (and estimated) to be unchanged.

In addition to all the variables that are included as regressors (inflation, the deviation of the real exchange rate from trend, and excess tradables demand), the set of instrumental variables includes the nominal quarterly average deposit interest rate (given its link to consumer expenditure through the transaction technology, (equations (7), (10)) and real wages in the manufacturing sector (since no data is available for the nontradables sectors). In both countries, dummies were included in the instrument set to account for currency crises; 1994:Q4 in Mexico and 1994:Q2 in Turkey.

\section{Estimation Results}

\section{Mexico}

Table 1 presents estimates of equation (34) with Mexican data for the period 1988:31999:4, using two different measures for tradables excess demand. Column a presents the regression results with the current account-to-GDP ratio as the proxy for tradables excess demand, and column $b$ with the imports-to-GDP ratio. Both the real exchange rate and the excess demand measure for tradables are estimated to have significant reduced form coefficients, supporting the notion that the excess demand for nontradables (as proxied by a linear combination of the two) is a significant driving force of nontradables inflation.

The $J$-test of overidentifying restrictions does not reject the specification in either case. With $\delta^{f}$ estimated to be statistically indistinguishable from 0.5 , the regression results indicate a significant deviation from fully forward looking behavior in nontradables pricing.

\section{Turkey}

Estimation results with Turkish data are reported in Table 2. As in the Mexican case, the specification comfortably passes the $J$-test of overidentifying restrictions. In the case where excess demand for tradables is proxied by the imports to GDP ratio (column b), both the real exchange rate and excess demand are estimated to have significant coefficients as in the Mexican case. In the other specification, the current account is estimated to have a significantly negative coefficient, and the real exchange a statistically insignificant coefficient, but this most likely reflects measurement error in the excess demand proxy. ${ }^{22}$

${ }^{22}$ In the Turkish case, workers remittances and other unclassified transfers from abroad have a large share in the current account, implying that the latter may not be a good indicator of the excess demand for tradable goods. 
Table 1. Mexico: Estimates of Equation (34), 1988: 3-1999:4

\begin{tabular}{|c|c|c|}
\hline & $\mathrm{a}$ & $\mathrm{B}$ \\
\hline$\delta^{f}$ & $0.464^{* *}$ & $0.417^{* *}$ \\
& $(0.083)$ & $(0.061)$ \\
\hline$\alpha_{1}$ & $0.014^{* *}$ & $0.018^{* *}$ \\
& $(0.004)$ & $(0.007)$ \\
\hline$\alpha_{2}$ & $0.013^{*}$ & $0.030^{* *}$ \\
& $(0.007)$ & $(0.007)$ \\
\hline $\begin{array}{c}\text { Measure of } \\
\text { tradables excess }\end{array}$ & $\begin{array}{c}\text { Current } \\
\text { account }\end{array}$ & Imports/GDP \\
\hline demand & deficit/GDP & \\
\hline p-value of $J$ test & 0.735 & 0.798 \\
\hline Number of \\
observations
\end{tabular}

Table 2. Turkey: Estimates of Equation (34), 1990: 1-2001:1

\begin{tabular}{|c|c|c|}
\hline & $\mathrm{a}$ & $\mathrm{b}$ \\
\hline$\delta^{f}$ & 0.820 & 0.728 \\
\hline$\alpha_{1}$ & $\left(0.089^{* *}\right)$ & $\left(0.088^{* *}\right)$ \\
\hline$\alpha_{2}$ & 0.035 & 0.058 \\
\hline & $(0.026)$ & $\left(0.028^{* *}\right)$ \\
\hline $\begin{array}{c}\text { Measure of tradables } \\
\text { excess demand }\end{array}$ & $\begin{array}{c}\left(0.109^{* *}\right) \\
\text { Current } \\
\text { account } \\
\text { deficit/GDP }\end{array}$ & $\begin{array}{c}(0.391 \\
\text { Imports/GDP }\end{array}$ \\
\hline p-value of $J$ test & 0.806 & 0.747 \\
\hline Number of observations & 46 & 46 \\
\hline
\end{tabular}


In both cases, however, the lagged inflation term is estimated to have a coefficient that is statistically significant at least at the 10 percent level, implying that nontradables inflation is partially sticky, though the point estimates of the lagged inflation coefficient are slightly smaller than in the Mexican case.

\section{POLICY EXPERIMENT: TEMPORARY STABILIZATION}

This section presents simulations of a temporary ERBS experiment using the model presented in Section II. The model dynamics for a temporary decline in the rate of devaluation are computed and compared for varying degrees of inflation stickiness.

\section{A. Calibration}

The parameter values used in the computational exercises are summarized in Table 3. Since the econometric estimates of the weight on lagged and expected future inflation in equation (17) are based on quarterly data, the time unit is a quarter. The expected duration of the program, $T$, is set to 12 quarters in all the simulations.

The benchmark case assumes fully forward-looking pricing behavior, so the weight on expected future inflation in equation (17) is set to $\delta^{f}=1$ in this case. In the other two simulations, the weight on expected future inflation is set to $\delta^{f}=0.7$ and $\delta^{f}=0.5$ respectively (in line with the Turkish and Mexican results). $B$, the coefficient of excess demand in equation (17) is set to $0.10{ }^{23}$ The steady state nominal depreciation rate, $\varepsilon^{H}$, is set to 70 percent p.a. The temporary rate of devaluation adopted in the ERBS program, $\varepsilon^{L}$, is 10 percent p.a. The real international interest rate facing the small open economy, $r$, is set to 10 percent p.a. The transaction cost function parameters are set to $k_{0}=4$ and $k_{1}=2$. The expenditure share of tradables consumption $q$ is set to 0.5 . The logarithmic utility specification equates both the intertemporal and intratemporal elasticities of substitution to one. ${ }^{24}$ The full capacity level of output, $y$, and the constant endowment of tradables, $y^{*}$, are both set equal to one. Initial net total foreign assets of the government and the private sector, $f_{-1}$, are set to zero.

${ }^{23}$ Given that nontradables excess demand is proxied with a linear combination of the deviation of the real exchange rate from trend and excess demand for tradables in the estimations, no estimate of the reduced form composite coefficient on excess nontradables demand, $B$, is available.

${ }^{24}$ This assumption is made for simplicity. Allowing for different values of the elasticities would complicate the dynamics without changing the comparative results of the numerical exercises. Moreover, econometric evidence in Ostry and Reinhart (1992) lends support to the assumption that the two elasticities are equal, as the 95 percent confidence bands of these two elasticities overlap in most of their regressions. 
Table 3. Parameter Values Used in the Model Simulations

\begin{tabular}{|c|c|l|}
\hline Parameter & Value & Description \\
\hline$T$ & 12 quarters & Duration of ERBS program \\
\hline$\delta^{f}$ & $1 / 0.7 / 0.5$ & Coefficient on future inflation in inflation dynamics \\
\hline$B$ & 0.1 & Coefficient on excess demand in inflation \\
\hline$\varepsilon^{H}$ & $70 \%$ p.a. & Steady state rate of nominal depreciation \\
\hline$\varepsilon^{L}$ & $10 \%$ p.a. & Temporary rate of nominal depreciation \\
\hline$r$ & $10 \%$ p.a. & Real international interest rate \\
\hline$k_{0}$ & 4 & Transaction cost parameter \\
\hline$k_{1}$ & 2 & Transaction cost parameter \\
\hline$q$ & 0.5 & Share of tradables in expenditure \\
\hline$y$ & 1 & Full capacity output of nontradables \\
\hline$y^{*}$ & 1 & Endowment of tradables \\
\hline$f_{-1}$ & 0 & Initial net foreign assets \\
\hline
\end{tabular}

\section{B. Simulation Results}

It is assumed that the economy is initially $(t<0)$ at the steady state associated with $\varepsilon^{H}$, characterized by equations (24), (25), (26), (27), and (28). At $t=0$, the government announces that the rate of devaluation will be permanently lowered to $\varepsilon^{L}$ from period $t=1$ onwards, but the public believes that this new regime will last for $T$ periods only. ${ }^{25}$ The expected path of nominal depreciation is:

${ }^{25}$ The expected duration of the stabilization program, $T$, is assumed to be exogenous and nonstochastic. Several studies relax this assumption (e.g. Calvo and Drazen, 1997, Mendoza and Uribe, 2001). While the latter is a more realistic scenario, the results in Mendoza and Uribe (2001) imply that these models require a rather specific exogenous structure of the evolution of policy reversal probability in order to match the qualitative aspects of the business cycle, especially the recession that follows the boom.

${ }^{26}$ As shown by Calvo and Végh (1993), the dynamics of the economy when the ERBS program is expected to last only $T$ quarters are identical to those that would prevail when the policy is indeed (and announced to be) temporary. 


$$
\varepsilon_{t}=\left\{\begin{array}{lll}
\varepsilon^{H} & \text { for } & t \leq 0 \\
\varepsilon^{L} & \text { for } & t=1, \ldots, T \\
\varepsilon^{H} & \text { for } & t \geq T+1, \ldots
\end{array}\right\}
$$

where $\varepsilon^{L}<\varepsilon^{H}$.

Given the uncovered interest parity condition (2), the decline in the rate of exchange rate depreciation in period $t=0$ translates into a drop in the nominal interest rate from $i=(1+r)\left(1+\varepsilon^{H}\right)-1$ to $i=(1+r)\left(1+\varepsilon^{L}\right)-1$, but the nominal interest rate is expected to reverse to $i=(1+r)\left(1+\varepsilon^{H}\right)-1$ in period $t=T$. Given the path of the nominal interest rate, the transaction cost technology ((4) and (10)) implies a constant and lower effective price of consumption during $t=0, \ldots, T-1$, and a constant and higher effective price from period $T$ onwards. This path of the effective price of consumption leads consumers to substitute their post-stabilization tradable goods consumption in favor of consumption in periods $t=0, \ldots, T-1$, when the effective price is relatively lower. By first order condition (7), this implies an upward jump in tradables consumption, $c^{*}$, in $t=0$. The level of $c^{*}$ remains constant during $t=0, \ldots, T-1$, since the nominal interest rate is constant during this period. ${ }^{27}$ In period $t=T$, with the increase in the nominal interest rate, $c^{*}$ jumps down to its permanent steady state level associated with $\varepsilon^{H}$, and remains constant. ${ }^{28}$

When the new policy is announced in period $t=0$, the real exchange rate $e_{0}$ is predetermined. With the relative price between tradables and nontradables consumption unchanged on impact, the first order condition (8) implies that the jump in $c^{*}$ is met by a jump of equal magnitude in $c$. The perfect foresight paths of $c$ and $\pi$ from $t=1$ onwards are determined by the equation system (23). Using the method of Binder and Pesaran (1995),

\footnotetext{
${ }^{27}$ Since tradables consumption is constant, so is the trade deficit, but the current account deficit increases over time due to interest payments on accumulated foreign debt.

${ }^{28}$ Notice that this new level of $c^{*}$ is lower than that before the ERBS, since the boom during $t=0, \ldots, T-1$ implies a depletion of foreign assets (or accumulation of external debt) to a level that can only support a lower level of tradables consumption.
} 
the system is solved for $\left[\pi_{t}, \log c_{t}\right]$ in terms of the predetermined variables $\left[\pi_{t-1}, \log c_{t-1}\right]$ and the current and future exogenous variables, $\left[\log \left(1+\varepsilon_{t+i}\right), \log c_{t+i}^{*}-\log c_{t+i-1}^{*}\right], i=0, \ldots, \infty{ }^{29}$ The solution takes the form:

$$
\left[\begin{array}{c}
\pi_{t} \\
\log c_{t}
\end{array}\right]=C\left[\begin{array}{c}
\pi_{t-1} \\
\log c_{t-1}
\end{array}\right]+F_{t}
$$

where $C$ is the solution of a quadratic determinantal equation, and $F_{t}$, which is the forward part of the solution, is a weighted averate of expected future values of the forcing variables. The solution paths are characterized for three different values of $\delta^{f}$. The solution paths of $c^{*}, c, \pi$, and $e$ in the baseline case where $\delta^{f}=1$ is depicted in Figure 2. The cases of $\delta^{f}=0.7$ and $\delta^{f}=0.5$ are shown in Figures 3 and 4 respectively.

In the baseline case, equation (17) implies that the excess demand created by the jump in nontradables consumption at $t=0$ prevents $\pi$ from immediately declining to its transitional steady state value, $\varepsilon^{L}$. In the two cases where $\delta^{f}<1$, in addition to excess demand, the effect of higher past inflation on current inflation also contributes to a slower reduction of inflation. The slow convergence on inflation to the rate of exchange rate depreciation effects a real exchange rate appreciation, which in turn lowers the demand for nontradables. Therefore, on the path of convergence to the (transitional) low inflation steady state nontradables consumption and the real exchange rate move in the same direction and initially they both decline. This is observed in Figures 2-4.

In the baseline case where $\delta^{f}=1$, both $c_{t}$ and $\pi_{t}$ decline during $t=1, \ldots T-1$ without overshooting their levels associated with the low-depreciation steady state (Figure 2). In the cases where $\delta^{f}<1$, inflation, and, therefore, the speed of real exchange rate appreciation are higher at the initial stages of the program, bringing about a faster reduction in nontradables consumption relative to the baseline case. As a result, the reduction in nontradables inflation is faster than in the baseline case, inflation reaches $\varepsilon^{L}$ more quickly when $\delta^{f}<1$ relative to when $\delta^{f}=1$. However, the adjustment towards the steady state is cyclical when $\delta^{f}<1$, with the real exchange rate appreciating further than its new steady state level, creating excess supply in the nontradables sector. This recession that follows the initial boom is the standard recessionary disinflation scenario associated with inflation stickiness, and is absent in the

${ }^{29}$ The path of the change in tradables consumption, $\log c_{t+i}^{*}-\log c_{t+i-1}^{*}$, is pinned down by the path of the nominal interest rate (or equivalently, the rate of nominal depreciation).

Therefore, $\log c_{t+i}^{*}-\log c_{t+i-1}^{*}$, may be treated as an exogenous variable in the determination of $\log c_{t}$ and $\pi_{t}$. 
Figure 2. $\delta^{f}=1, B=0.1$

Tradables Consumption

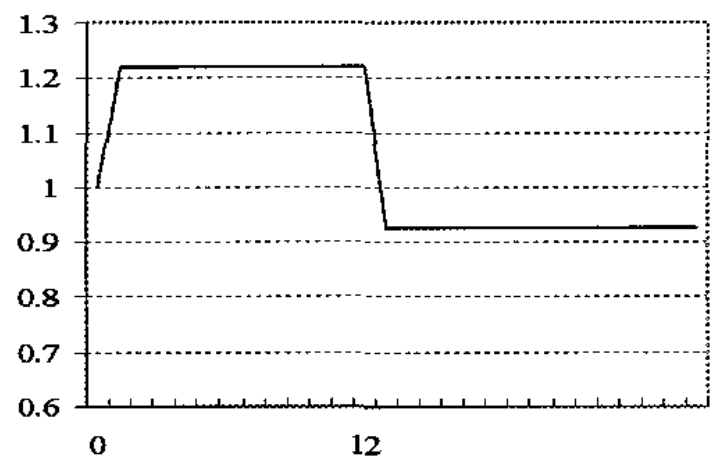

Nontradables Inflation

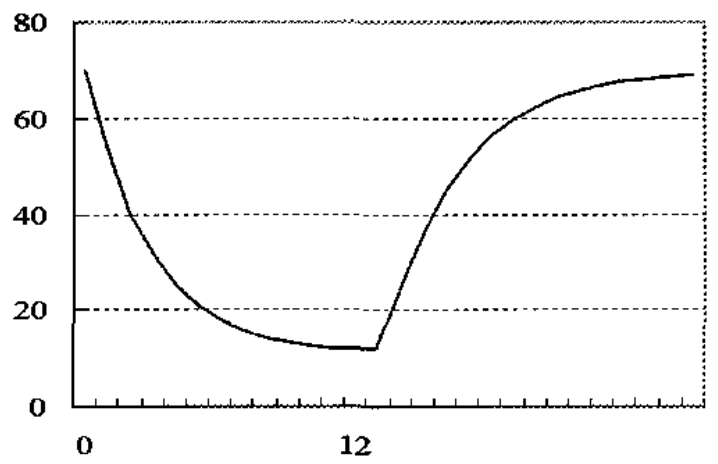

Nontradables Consumption
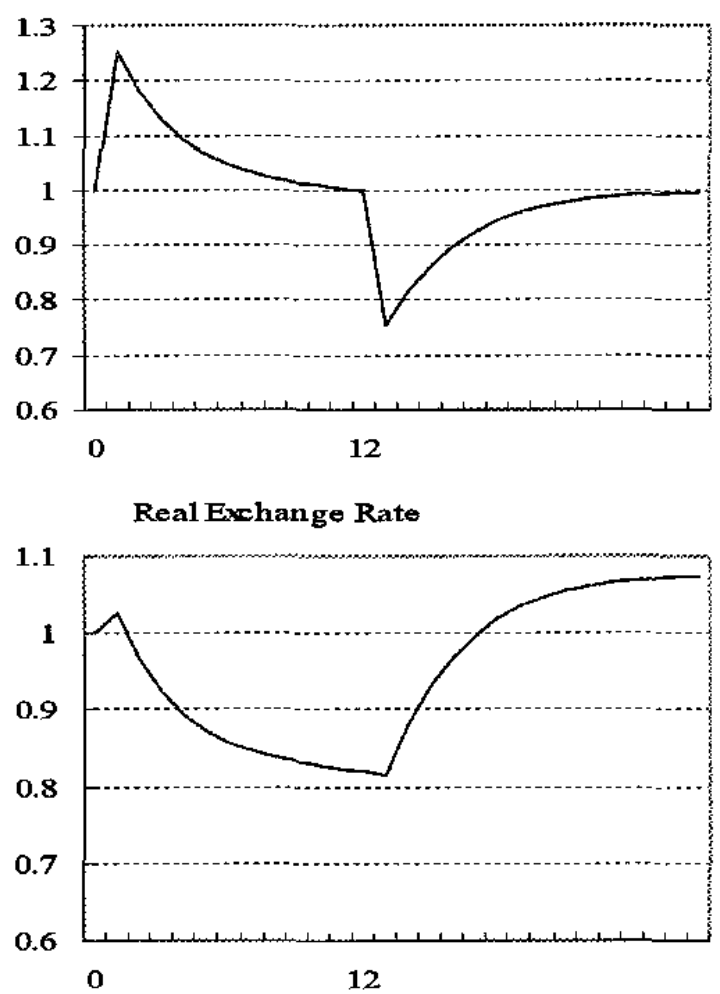
Figure 3. $\delta^{f}=0.7, B=0.1$
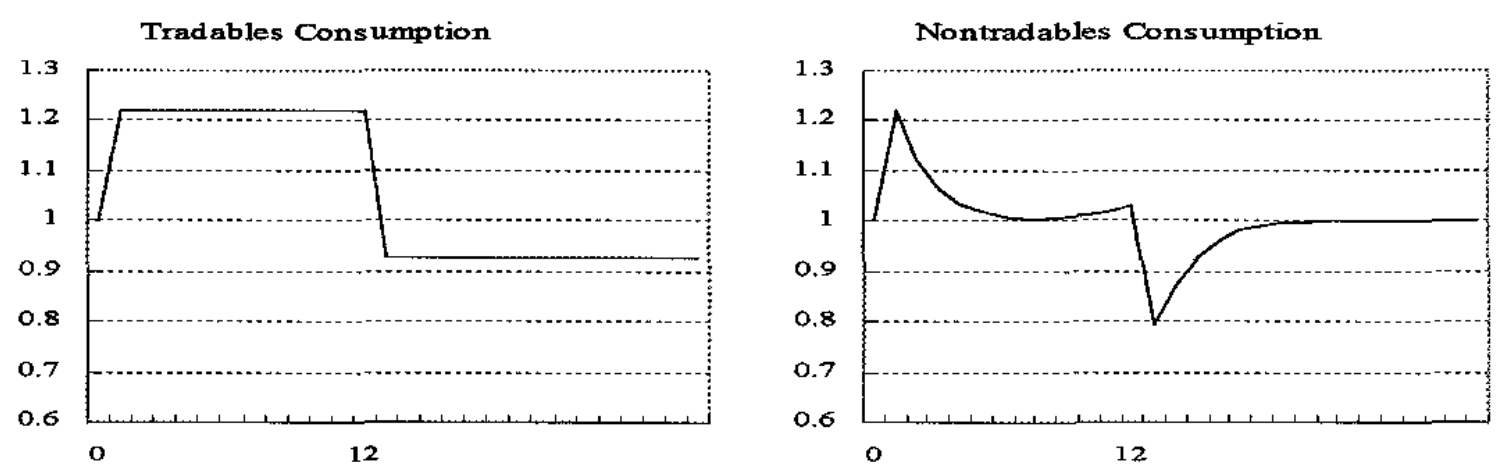

Nontradables Inflation
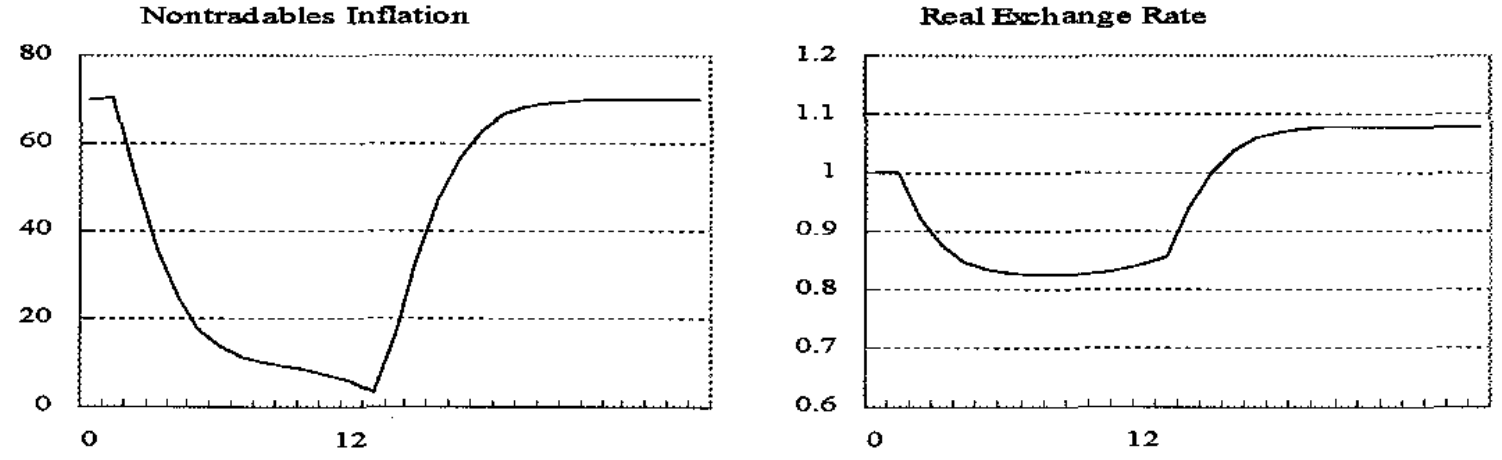
Figure 4. $\delta^{f}=0.5, B=0.1$
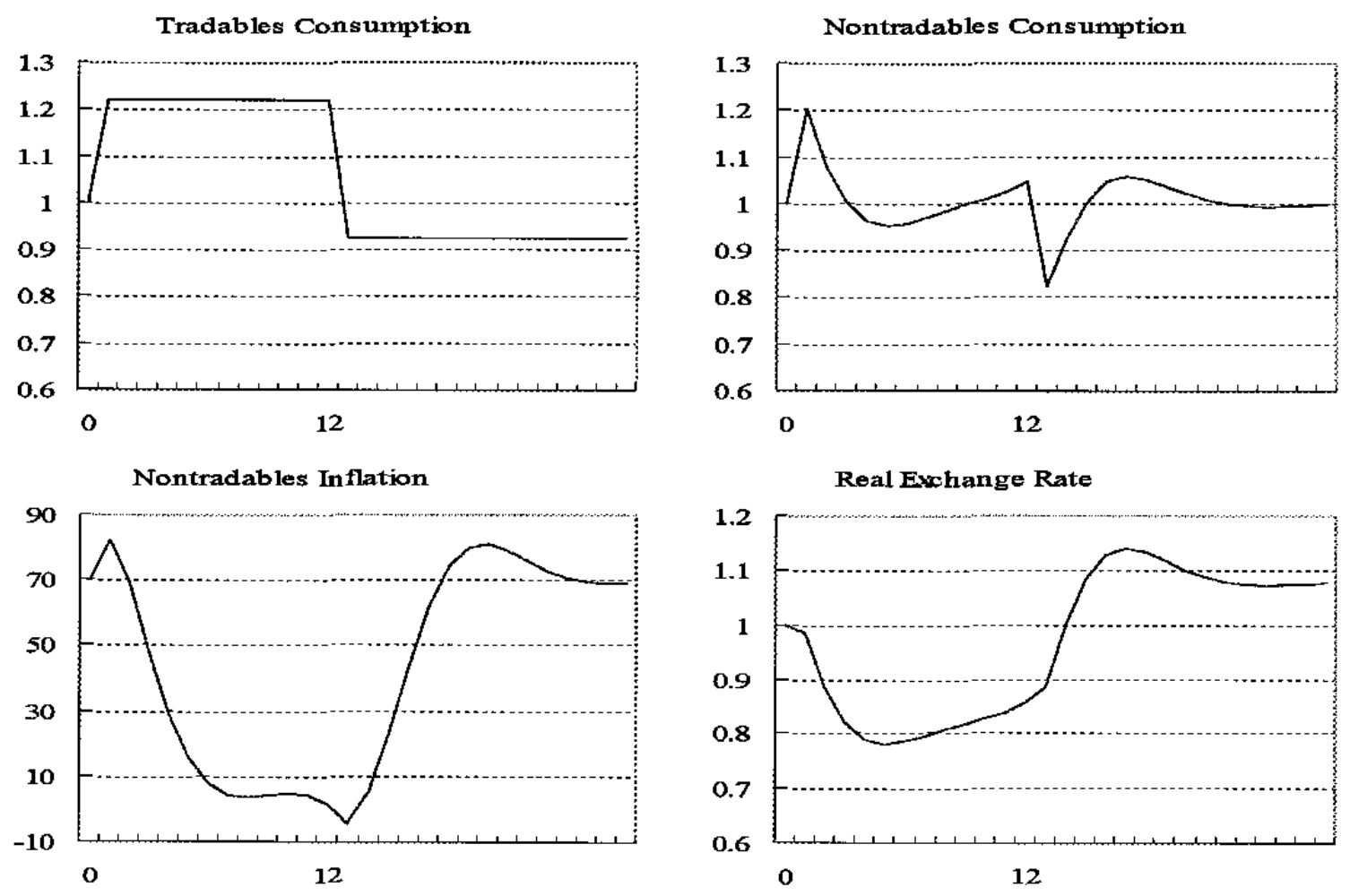
forward-looking case with $\delta^{f}=1{ }^{30}$ The presence of the initial consumption boom due to imperfect policy credibility postpones the recession.

At the time of policy reversal, $t=T$, when tradables consumption jumps down on account of the high nominal interest rate between periods $T$ and $T+1$, it follows from first order condition (8) that nontradables consumption also jumps down, given that the nontradables price level is sticky and, therefore, the real exchange rate is predetermined. Excess supply in the nontradables sector, as well as the effect of past inflation when $\delta^{f}<1$, prevent nontradables inflation from immediately increasing, instead, the convergence of $\pi$ to $\varepsilon^{H}$ is gradual.

The simulation experiments suggest that, the presence of stickiness in inflation is hard to reconcile with the large and persistent consumption booms observed in the initial stages of ERBS plans on account of most existing models of the ERBS boom-recession cycle. Inflation stickiness helps to rationalize recession that occurs in the later stages of ERBS plans, but it reduces the persistence of the initial consumption boom. While price stickiness is a key element for the lack of credibility hypothesis in explaining the spillover of the expansion in the tradables sector to the nontradables sector, inflation stickiness reduces the persistence of the initial nontradables consumption boom, worsening the model's performance in matching the quantitative properties of the ERBS business cycle.

\section{ConClusion}

The inability to account for the large consumption booms experienced in the initial stages of ERBS plans is an important shortcoming of the lack-of-credibility hypothesis. This paper presents econometric evidence from Mexico and Turkey that points to the quantitative significance of stickiness in inflation and shows in a calibrated general-equilibrium model that inflation stickiness contributes to a more rapid appreciation of the real exchange rate in the early stages of ERBS, which further reduces the persistence of the initial consumption boom predicted by the lack-of-credibility model. On the other hand, it is shown that sticky inflation helps to rationalize the recession that takes hold in the later stages of ERBS programs, as originally suggested by Dornbusch (1982) and Rodriguez (1982).

The simulation results presented in this paper point to the fact that the literature has an unfinished agenda in terms of explaining the persistent effects of ERBS plans on the real economy. While rigidities in prices and inflation help in explaining the qualitative properties of the ERBS business cycle, they make it more difficult to explain the persistent real effects. The empirical results of the paper raise the issue of why inflation is relatively more sticky in the nontradables sector than in the tradables sector, which is another promising topic for further theoretical research.

${ }^{30}$ See, for example, Calvo and Végh (1994) for an exposition in an open-economy context. 


\section{Appendix}

The derivation of the forward looking pricing rule follows Calvo (1982). Suppose that a firm that receives a price-change signal in period $t$ chooses a reset price $v_{t}$ which applies from period $t$ onwards (until a new signal is received). The real profits of a firm in any period $\mathrm{s}, s \geq t$, is denoted by $z(s)=z\left(V_{t}, P_{s}, c_{s}, d_{s}\right)$, where $V_{t}$ is the logarithm of $v_{t}, P_{s}$ is the logarithm of $p_{s}$, the aggregate price level in period $s, c_{s}$ is a measure of the firms costs, and $d_{s}$ is a measure of aggregate demand in period $s$. The expected profit associated with $V_{t}$ is:

$$
Z(t)=z(t)+\sum_{k=1}^{\infty}\left(\sum_{i=k}^{\infty}(1-\gamma) \gamma^{i}\right) z(t+k)
$$

which can be rewritten as:

$$
Z(t)=\sum_{k=0}^{\infty} \gamma^{k} E_{t} z\left(V_{t}, P_{t+k}, c_{t+k}, d_{t+k}\right)
$$

Let the single period optimal price be denoted as $V_{s}^{*}$, where $V_{s}^{*}=\underset{V}{\arg \max } z\left(V, P_{s}, c_{s}, d_{s}\right)$. A second-order linear approximation to $z(s)$ around $V_{s}^{*}$ yields:

$$
\begin{gathered}
Z(t)=\sum_{k=0}^{\infty} \gamma^{k} E_{t}\left[z\left(V_{t+k}^{*}, P_{t+k}, c_{t+k}, d_{t+k}\right)\right. \\
+z_{V}^{\prime}\left(V_{t+k}^{*}, P_{t+k}, c_{t+k}, d_{t+k}\right)\left(V_{t}-V_{t+k}^{*}\right) \\
\left.+\frac{1}{2} z_{V}{ }^{\prime \prime}\left(V_{t+k}^{*}, P_{t+k}, c_{t+k}, d_{t+k}\right)\left(V_{t}-V_{t+k}^{*}\right)^{2}\right]
\end{gathered}
$$

Notice that $z_{V}{ }^{\prime}\left(V_{t+k}^{*}, P_{t+k}, c_{t+k}, d_{t+k}\right)=0$ by construction. It is assumed that $z_{V V}$ "(.), the second derivative of $z($.), does not vary much over time, so we approximate it to $\kappa$. The profit maximizing choice of $V_{t}$ then satisfies the following first order condition:

$$
\frac{\partial Z(t)}{\partial V_{t}}=\kappa \sum_{k=0}^{\infty} \gamma^{k} E_{t}\left(V_{t}-V_{t+k}^{*}\right)=0
$$

which implies equation (13) in the text:

$$
V_{t}=(1-\gamma) \sum_{k=0}^{\infty} \gamma^{k} E_{t} V_{t+k}^{*}
$$

We now turn to the derivation of $V_{s}^{*}$, the optimal single-period price for $s$. The recent literature (e.g., Galí and Gertler, 1999) assume a monopolistic-competition environment where the optimal price is a markup over nominal marginal costs. In such an environment, the demand for a firm with price $v_{s}^{*}$ is (note that lower case $v_{s}^{*}$ and $p_{s}$ are the antilogs of their upper case versions): 


$$
\left(\frac{v_{\mathrm{s}}^{*}}{p_{\mathrm{s}}}\right)^{-\varsigma} e d_{s}
$$

where $\varsigma$ is the elasticity of demand, and ed excess demand, where $0<e d<\infty$ and $e d=1$ corresponds to full employment. Suppose that labor is the only input into production, and $L$ units of labor produces $L^{1 / \theta}$ units of output. Period $s$ real profits then are:

$$
\left(\frac{v_{\mathrm{s}}^{*}}{p_{\mathrm{s}}}\right)^{1-\varsigma} e d_{s}-\frac{\varpi_{s}}{p_{\mathrm{s}}}\left(\frac{v_{\mathrm{s}}^{*}}{p_{\mathrm{s}}}\right)^{-\varsigma \theta} e d_{s}^{\theta}
$$

where $\varpi_{s}$ is the unit nominal wage. The first order condition with respect to $\frac{v_{s}^{*}}{p_{s}}$ yields the following relationship:

$$
(\varsigma-1)\left(\frac{v_{s}^{*}}{p_{s}}\right)^{-\varsigma}=\frac{\varpi_{s}}{p_{s}} \varsigma \theta\left(\frac{v_{s}^{*}}{p_{s}}\right)^{-(1+\varsigma \theta)} e d_{s}^{\theta-1}
$$

Assuming that $\frac{w_{s}}{p_{s}}$ is constant over time, and taking logs, the expression may be rewritten as:

$$
V_{s}^{*}=c+P_{s}+\frac{\theta-1}{1+\varsigma(\theta-1)} \log \left(e d_{s}\right)
$$

which, ignoring the constant, and letting $\beta=\frac{\theta-1}{1+\varsigma(\theta-1)}$, is the relationship used in equation (13). This is also the approximation used in Calvo (1983). If the real wage is assumed to vary over time, we get:

$$
V_{s}^{*}=c+P_{s}+\frac{1}{1+\varsigma(\theta-1)} \log \left(\frac{\varpi_{s}}{p_{s}}\right)+\frac{\theta-1}{1+\varsigma(\theta-1)} \log \left(e d_{s}\right)
$$

which implies that the real wage should enter equations (17, and (34) as an additional forcing variable. Since the real wage (in the manufacturing sector) failed to enter the estimated structural nontradables inflation equations in a satisfactory manner for both Turkey and Mexico, perhaps reflecting error in measurement, it is assumed to be constant. 


\section{References}

Bruno, M., 1993, Crisis, Stabilization, and Economic Reform: Therapy by Consensus, (Oxford: Oxford University Press).

Burstein, A. T., J. C. Neves, S. Rebelo, 2001, Distribution Costs and Real Exchange Rate Dynamics during Exchange-Rate-Based-Stabilizations, forthcoming, Journal of Monetary Economics.

Calvo, G. A., 1982, "On the Microfoundations of Staggered Contracts: A First Approximation," Unpublished working paper.

— 1983 , "Staggered Prices in a Utility Maximizing Framework, " Journal of Monetary Economics, No. 12, pp. 383-98.

1986, "Temporary Stabilization: Predetermined Exchange Rates," Journal of Political Economy, No. 94: pp. 1319-29.

O. Celasun, and M. Kumhof, 2003, "A Theory of Rational Inflation Inertia," in P. Aghion, R. Frydman, J. Stiglitz and M. Woodford, eds., Knowledge, Information and Expectations in Modern Macroeconomics: In Honor of Edmund S. Phelps, (Princeton: Princeton University Press).

Calvo, G. A., and C. A. Végh, 1993, "Exchange Rate Based Stabilization Under Imperfect Credibility," in Helmut Frisch and Andreas Worgotter, eds., Open Economy Macroeconomics, (London: MacMillan Press), pp. 3-28.

— , 1994a, "Stabilization Dynamics and Backward Looking Contracts," Journal of Development Economics, No. 43, pp.59-84.

_ 1994b, "Credibility and the Dynamics of Stabilization Policy: A Basic Framework," in C.Sims ed., Advances in Econometrics:Sixth World Congress, Vol.II, (Cambridge: Cambridge University Press), pp. 377-420.

__, 1999, "Inflation Stabilization and BOP Crises in Developing Countries," ed. by John Taylor and Michael Woodford, (North-Holland: Handbook of Macroeconomics), pp. 1531-1614.

Celasun, O., 2001, "Are Price Setters Forward Looking? Evidence from Mexico and Turkey," Chapter II, Ph. D. Dissertation, (College Park, Maryland: University of Maryland).

De Gregorio, J., P.E., Guidotti, and C.A., Végh, 1998, "Inflation Stabilization and the Consumption of Durable Goods," Economic Journal, No. 108, pp. 105-31. 
Dornbusch, R., (1982) "Stabilization Policies in Developing Countries: What Have We Learned?, World Development, No. 10, pp. 701-8.

—, and A. Werner, 1994, "Mexico: Stabilization, Reform and No Growth," Brookings Papers in Economic Activity, No. 1, pp. 253-315.

Drazen, A., and E. Helpman, 1988, "Stabilization with Exchange Rate Management Under Uncertainty," in Economic Effects of the Government Budget, ed. by E. Helpman, A. Razin and E. Sadka (Cambridge, Massachussets: MIT Press) pp. 310-27.

Fuhrer, J. and G. Moore, 1995, "Inflation Persistence," Quarterly Journal of Economics, Vol. 110. No. 1, pp. 127-159.

Galí, J., and M. Gertler, 1999, "Inflation Dynamics: A Structural Econometric Analysis," Journal of Monetary Economics, No. 44, pp. 195-222.

—_ and D. López-Salido, 2001, "European Inflation Dynamics," European Economic Review, Vol. 45, No. 7, pp. 1237-70.

Ghezzi, P., 2001, "Backward-looking Indexation, Credibility and Inflation Persistence," Journal of International Economics, Vol. 53, No. 1, pp. 127-47.

Hansen, L.P., 1982, "Large Sample Properties of Generalized Method of Moment Estimators," Econometrica, No. 50, pp. 1029-54.

—, and T. Sargent, 1980, "Instrumental Variables Procedures for Estimating Linear Rational Expectations Models," Journal of Monetary Economics, No. 9, pp. 263-69.

Hayashi, F., 1980, "Estimation of Macroeconometric Models Under Rational Expectations: A Survey," Discussion Paper (Evanston, Illlinois: Northwestern University.)

Helpman, E, and A. Razin, 1987, "Exchange Rate Management: Intertemporal Tradeoffs," American Economic Review, No. 77, pp. 107-23.

Kimbrough, K., 1986, "The Optimal Quantity of Money Rule in the Theory of Public Finance," Journal of Monetary Economics, No. 18, pp. 277-87.

Lahiri, A., 1996, "Exchange Rate Based Stabilizations Under Real Frictions: The Role of Endogenous Labor Supply," University of California, Los Angeles Department of Economics Working Paper No. 759.

Mankiw, N.G., and R. Reis, 2002, "Sticky Information Versus Sticky Prices: A Proposal to Replace the New Keynesian Phillips Curve," Quarterly Journal of Economics, Vol. 117, No. 4, pp. 1295-1328. 
McCallum, B., 1976, "Rational Expectations and the Natural Rate Hypothesis: Some Consistent Estimates," Econometrica, No 44, pp. 43-52.

Mendoza, E., and M. Uribe, 2001, "Devaluation Risk and the Business Cycle Implications of Exchange Rate Management, " Carnegie Rochester Conference Series on Public Policy, No. V, pp. 53, 2001.

Obstfeld, M., 1995, "International Currency Experience: New Lessons and Lessons Relearned," Brookings Papers on Economic Activity, No. 1, pp. 119-96.

Ostry, J., and C. M. Reinhart, 1992, "Private Saving and Terms of Trade Shocks," IMF Staff Papers, No. 39, pp. 495-517.

Rebelo, S., 1993, "Inflation in Fixed Exchange Rate Regimes: The Recent Portugese Experience," in Torres and Giavazzi (eds.), Adjustment and Growth in the European Monetary Union, Cambridge University Press, 1993. and C. A. Végh, 1995, "Real Effects of Exchange Rate-Based Stabilization: An Analysis of Competing Theories," NBER Macroeconomics Annual, pp. 125-74.

Reinhart, C. M., and C. A. Végh, 1994, "Inflation Stabilization in Chronic Inflation Countries," mimeo, International Monetary Fund.

—_ 1995, "Nominal Interest Rates, Consumption Booms, and Lack of Credibility: A Quantitative Examination," Journal of Development Economics, No. 46, pp. 357-78.

Rodriguez, C. A., 1982, "The Argentine Stabilization plan of December 20th," World Development, No. 10: pp. 801-11.

Roldos, J., 1995, "Supply Side Effects of Disinflation Programs," IMF Staff Papers, March 1995, No. 42 Vol. 1, pp. 158-83.

Uribe, M., 1999, "Exchange-Rate-Based Inflation Stabilization: The Initial Real Effects of Credible Plans," Journal of Monetary Economics, No. 39 Vol. 2, pp. 197-221. 